\title{
Impact of working capital management on firm's profitability: an application on BIST tourism companies
}

\author{
Turhan Korkmaz ${ }^{1}$, Serdar Yaman ${ }^{2}$
}

\begin{abstract}
In this study, the effect of the working capital management on the profability of tourism firms that are trading in Borsa Istanbul (BIST) has been analyzed for the period after the crisis 2008. The study covers semi-annual data of 6 tourism firms operated in Turkey for the period of 2011:12-2017:12. In the study, Th effect of working capital management on the profability of firms has been analyzed using panel data analysis. The effect of cash conversion cycle (CCC) and its components which are considered as the basic indicators of the working capital on profability of tourism firms has been analyzed separately as independent variables in separate models. According to the results of the study, it has been determined that cash conversion cycle, accounts receivables period and inventory turnover period have statistically significant negative effects on profability of tourism firms. On the other hand, it has been determined that accounts payables period has statistically significant positive effect on profability of tourism firms.
\end{abstract}

Keywords: Working Capital Managemet, Firm Profability, BIST Tourism Companies, Cash Conversion Cycle.

\section{Çalışma sermayesi yönetiminin firma karlılığına etkisi: BIST turizm firmaları üzerine bir uygulama ${ }^{3}$}

\section{$\ddot{O} z$}

Bu çalışmada, çalı̧̧ma sermayesi yönetiminin Borsa İstanbul (BİST)'da faaliyet gösteren turizm firmalarının firma karlılıkları üzerine olan etkisi 2008 krizi sonrası dönem için incelenmiştir. Çalışma 2011:12-2017:12 döneminde Türkiye'de turizm sektöründe faaliyet gösteren 6 turizm firmasına ilişkin altı aylık verileri kapsamaktadır. Çalışmada, çalıșma sermayesi yönetimin firma karlılı̆̆ üzerindeki etkisi panel veri analizi yöntemi kullanılarak incelenmiştir. Çalışma sermayesinin temel göstergesi olarak kabul edilen nakit dönüşüm süresi ve bileşenleri ayrı modellerde bağımsız değişken olarak ele alınarak turizm firmalarının karlılıkları üzerindeki etkileri incelenmiştir. Çalışmanın sonuçlarına göre, nakit dönüşüm süresi, alacak tahsil süresi ve stok devir süresi turizm firmalarının faaliyet karlılıkları üzerinde istatistiki olarak negatif anlamlı etkiye sahip olduğu tespit edilmiştir. Diğer yandan borçların ödenme süresinin ise turizm firmalarının faaliyet karlılıklarl üzerinde pozitif anlamlı etkiye sahip olduğu tespit edilmiştir.

Anahtar sözcükler: Çalışma Sermayesi Yönetimi, Firma Karlılı̆̆ı, BíST Turizm Firmaları, Nakit Dönüşüm Süresi

$\begin{array}{ll}\text { Geliş Tarihi } & : 27.09 .2018 \\ \text { Kabul Tarihi } & : 01.03 .2019\end{array}$

Alıntı için: Korkmaz, T., Yaman, S. (2019). Çalışma sermayesi yönetiminin firma karlılığına etkisi: BIST turizm firmaları üzerine bir uygulama. Journal of Tourism Theory and Research, 5(2), 301-316.

\footnotetext{
1 e-mail: korktur@gmail.com

e-mail: srdr73@gmail.com

${ }^{3}$ Bu çalışma 27-29 Eylül tarihlerinde Mersin'de düzenlenen The Second International Congress on Future of Tourism: Innovation, Entrepreneurship and Sustainability isimli kongrede bildiri olarak sunulmuş̧tur.
} 


\section{Giriş}

Gerek ulusal gerekse uluslararas1 piyasalarda yoğun rekabet koşulları altında faaliyet göstermek durumunda olan firmalar, üretimlerini kesintisiz bir şekilde sürdürebilme, tam kapasite ile çalışabilme, faaliyetlerini verimli ve karlı bir şekilde devam ettirebilme, likidite risklerini azaltabilme ve kredi değerliliklerini artırabilme gibi önemli konularda etkin bir çalışma sermayesi yönetimine ihtiyaç duymaktadırlar. Çalışma sermayesi en basit şekliyle bir firmadaki dönen varlıkların değerini ifade etmektedir. Çalışma sermayesi unsurları esas itibariyle nakit ve nakit benzerleri, ticari alacaklar ve stoklara yapılan yatırımlardan oluşmaktadır (Ata ve Buğan, 2016: 26). Dolayısıyla çalışma sermayesi, bir işletmenin günlük faaliyetlerini yerine getirebilmesi için gerekli olan fonlar ile ilgilidir. Kısa vadeli varlıkları ifade eden çalışma sermayesinin finansmanında esas olarak kısa vadeli yükümlülükler kullanılmaktadır. Dolayısıyla firmaların çalışma sermayelerinin en önemli finansman kaynağ1 ticari borçlar olmaktadır. İşletmelerin özellikle stoklarının finansmanında ticari borçlar nakit çıkışlarını zamana yayarak önemli bir finansman kaynağı oluşturmaktadır. Dönen varlıklar ve kısa vadeli yükümlülükler arasındaki uyum düzeyi ise çalışma sermayesi yönetiminin temel amacını oluşturmaktadır (Keskin ve Gökalp, 2016: 16).

Çalışma sermayesinin yönetiminin ölçümünde en sık kullanılan ölçüt, nakit dönüşüm süresidir. $\mathrm{Bu}$ ölçüt ilk olarak Gitman tarafindan geliştirilmiştir (Gitman, 1974; akt. Keskin ve Gökalp, 2016: 16). Bir firmanın çalışma sermayesi yatırımlarını etkileyen üretim döngüsünde dört anahtar tarih söz konusudur. Firmalar üretim döngüsüne hammaddeleri satın alarak başlamakta, fakat çoğu zaman satın alınan hammaddelerin ödemelerini hemen yapmamaktadırlar. Ödemelerdeki söz konusu gecikme ticari borçları ödeme süresi olarak adlandırılmaktadır. Firmalar hammaddeleri işler ve sonrasında üretilen mamülü veya hizmeti satar. Stoklara ilk yatırım ile satışın gerçekleştiği tarih arasında geçen süre stokta geçen süre olarak adlandırılmaktadır. Firmalar sattıkları ürünlerin veya hizmetlerin karşıllı̆ııı hemen tahsil edemeyebilirler. Satış tarihi ile müşterilerin ödemelerin yaptıkaları tarih arasında geçen süre ise ticari alacakların tahsil süresi olarak adlandırılır (Brealey vd., 2007:523). Nakit dönüşüm süresi, firmanın stokta geçen süresi ile alacak ticari alacakların tahsil süresinin toplamından ticari borçları ödeme süresinin çıkartılması ile bulunur. Nakit dönüşüm süresinin uzaması satışların artması nedeni ile kârlılığı arttırabilir. Bunun yanı sıra çalışma sermayesine yapılan yatırımın maliyetinin stoklara ve ticari alacaklara yapılan yatırımdan sağlanan faydadan fazla olması durumda nakit dönüşüm süresinin uzaması karlılığ1 azaltabilir (Deloof, 2003: 574).

Bu çalışmada, Borsa İstanbul (BİST)' da işlem gören 6 adet turizm firmasının 2011:12-2017:12 dönemi verileri kullanılarak kriz sonrası dönem için çalışma sermayesi yönetimi ile firma karlılığı arsındaki ilişkinin incelenmesi amaçlanmıştır. Çalıșmada, bağımlı değișken olarak faaliyet karlılık oranı kullanılırken, bağımsız değişken olarak; çalışma sermayesinin temel göstergesi olarak kabul edilen nakit dönüşüm süresi ve bileşenleri olan stok devir süresi, alacak tahsil süresi ve borçların ödenme süresi kullanılmıştır. Nakit dönüşüm süresi ve bileşenlerinden her biri ayrı modellerde bağımsız değişken olarak kullanılmıştır.

Çalışma beş bölümden oluşmaktadır. Giriş'den sonraki ikinci bölümde, finansal performansı ölçmek için çalışma sermayesi yönetimi ile firma karl1lığ arasındaki ilişkiyi çeşitli yöntemlerle inceleyen yurtiçi ve yurtdışı çalışmaların yer aldığı literatür çalışmasına yer verilmiştir. Çalışmanın üçüncü bölümünde, araştırmanın amacı, kapsamı, kullanılan veri seti ve takip edilen metodoloji anlatılmıştır. Dördüncü bölümde, araştırmanın bulgularına yer verilerek nakit dönüşüm süresi ve her bir bileşeninin yer aldığı modeller için elde edilen analiz sonuçları ayrı ayrı yorumlanmış ve nakit dönüşüm süresi ve bileşenlerinin firma karlılıkları üzerindeki etkileri karşılaştırılmıştır. Beşinci ve son bölümde ise, sonuç ve önerilere yer verilmiştir. 


\section{Literatür taraması}

Çalışmanın bu bölümünde çalışma sermayesi yönetimi ile firma karlılığ celeyen bazı çalışmaların yer aldığı literatür taramasına yer verilmiştir. Yapılan literatür taramasında çalışma sermayesi yönetimi ile firma karlılığ 1 arasındaki ilişkiyi inceleyen çalışmalarda firma karlılığının genellikle Aktif Karlılığı ve Faaliyet Karlılığı ile, çalışma sermayesi yönetiminin ise Nakit Dönüşüm Süresi ve bileşenleri ile temsil edildiği görülmektedir. Literatürdeki çalışmalarda modeller oluşturulurken bazı değişkenlerin de kontrol değişkeni olarak modele eklendiği görülmektedir. Finansal Kaldıraç Oranı, Cari Oran ve Satışlardaki Büyüme Oranı değişkenlerinin literatürde sıklıkla kontrol değişkeni olarak modellere dahil edildikleri görülmektedir. Çalışma sermayesi yönetimi ile firma karlılığı arasındaki ilişkiyi inceleyen çalışmalara ilişkin bilgiler Tablo 1'de verilmiştir.

Tablo 1. Çalışma Sermayesi ile Firma Karlılı̆ğ Arasındaki İlişkiyi İnceleyen Çalışmalar

\begin{tabular}{|c|c|c|c|c|c|c|}
\hline Yazar(lar) & Dönem & $\begin{array}{l}\text { Ülke / Ör- } \\
\text { neklem }\end{array}$ & Yöntem & Değişkenler & \multicolumn{2}{|c|}{$\begin{array}{l}\text { Değişkenlere İlişkin } \\
\text { Bulgular } \\
\text { İlişkinin Yönü }\end{array}$} \\
\hline Wang (2002) & $\begin{array}{l}1985- \\
1996\end{array}$ & $\begin{array}{l}\text { Japonya ve } \\
\text { Tayvan }\end{array}$ & Korelasyon analizi & $\begin{array}{l}{ }^{*} \text { Karlilık } \\
\text { NDS }\end{array}$ & \multicolumn{2}{|l|}{ Negatif } \\
\hline $\begin{array}{l}\text { Deloof } \\
\text { (2003) }\end{array}$ & $\begin{array}{l}1991- \\
1996\end{array}$ & Belçika & Regresyon analizi & $\begin{array}{l}\text { *Brüt faaliyet karı } \\
\text { ATS } \\
\text { BÖS } \\
\text { SDS } \\
\text { Finansal kaldıraç } \\
\text { Firma büyüklüğü } \\
\text { Satışlarda büyüme } \\
\text { NDS } \\
\end{array}$ & \multicolumn{2}{|l|}{$\begin{array}{l}\text { Negatif } \\
\text { Negatif } \\
\text { Negatif } \\
\text { Negatif } \\
\text { Pozitif } \\
\text { Pozitif } \\
\text { İlişki yok }\end{array}$} \\
\hline $\begin{array}{l}\text { Lazaridis ve } \\
\text { Tryfonidis } \\
\text { (2006) }\end{array}$ & $\begin{array}{l}2001- \\
2004\end{array}$ & Yunanistan & Regresyon analizi & $\begin{array}{l}\text { *Brüt faaliyet karı } \\
\text { NDS } \\
\text { ATS } \\
\text { SDS } \\
\text { BÖS } \\
\text { Sabit finansal varlıklar } \\
\text { Finansal borçlar } \\
\text { Satışlarda büyüme } \\
\end{array}$ & \multicolumn{2}{|l|}{$\begin{array}{l}\text { Negatif } \\
\text { Pozitif } \\
\text { Negatif } \\
\text { Pozitif } \\
\text { Pozitif } \\
\text { Negatif } \\
\text { Pozitif }\end{array}$} \\
\hline $\begin{array}{l}\text { Garcia-Te- } \\
\text { ruel ve Mar- } \\
\text { tinez-Solano } \\
(2007)\end{array}$ & $\begin{array}{l}1996- \\
2002\end{array}$ & İspanya & Panel veri analizi & $\begin{array}{l}\text { *Aktif karlılığı } \\
\text { ATS } \\
\text { SDS } \\
\text { BÖS } \\
\text { NDS } \\
\text { Firma büyüklüğü } \\
\text { Satışlarda büyüme } \\
\text { Finansal kaldıraç } \\
\text { GSYIH büyüme } \\
\end{array}$ & \multicolumn{2}{|l|}{$\begin{array}{l}\text { Negatif } \\
\text { Negatif } \\
\text { Negatif } \\
\text { Negatif } \\
\text { Pozitif } \\
\text { Pozitif } \\
\text { Negatif } \\
\text { Negatif }\end{array}$} \\
\hline $\begin{array}{l}\text { Singh ve } \\
\text { Pandey } \\
(\mathbf{2 0 0 8 )}\end{array}$ & $\begin{array}{l}1990- \\
2007\end{array}$ & Hindistan & $\begin{array}{l}\text { Çoklu doğrusal } \\
\text { regresyon analizi }\end{array}$ & $\begin{array}{l}\text { *Vergi öncesi kar } \\
\text { Cari oran } \\
\text { Likidite oranı } \\
\text { Çalışma sermayesi oranı } \\
\text { Stok devir hızı } \\
\text { Alacak tahsil süresi } \\
\text { Çalışma sermayesi/toplam aktif }\end{array}$ & \multicolumn{2}{|l|}{$\begin{array}{l}\text { Negatif } \\
\text { Pozitif } \\
\text { İlişki yok } \\
\text { İlişki yok } \\
\text { Pozitif } \\
\text { Pozitif }\end{array}$} \\
\hline $\begin{array}{l}\text { Nazir ve } \\
\text { Afza (2009) }\end{array}$ & $\begin{array}{l}1998- \\
2005\end{array}$ & Pakistan & Panel veri analizi & $\begin{array}{l}\text { *Aktif karlılığı (ROA) } \\
\text { *Tobin's Q } \\
\text { Dönem varlık/toplam aktif } \\
\text { Toplam borç/toplam aktif } \\
\text { Firma büyüklüğü } \\
\text { Satışlarda büyüme } \\
\text { GSYİH büyüme } \\
\text { Finansal kaldıraç }\end{array}$ & $\begin{array}{l}\text { ROA } \\
\text { Negatif } \\
\text { Pozitif } \\
\text { Pozitif } \\
\text { İlişki yok } \\
\text { İlişki yok } \\
\text { Negatif }\end{array}$ & $\begin{array}{l}\begin{array}{l}\text { To- } \\
\text { bin'sQ }\end{array} \\
\text { Pozitif } \\
\text { Pozitif } \\
\text { Pozitif } \\
\text { İlişki } \\
\text { yok } \\
\text { Pozitif } \\
\text { İlişki } \\
\text { yok }\end{array}$ \\
\hline
\end{tabular}




\begin{tabular}{|c|c|c|c|c|c|c|}
\hline $\begin{array}{l}\text { Gill vd. } \\
\text { (2010) }\end{array}$ & $\begin{array}{l}2005- \\
2007\end{array}$ & ABD & Panel veri analizi & $\begin{array}{l}\text { *Faaliyet karlılı̆̆ } \\
\text { ATS } \\
\text { BÖS } \\
\text { SDS } \\
\text { NDS } \\
\text { Firma büyüklüğ̈ } \\
\text { Finansal kaldraç oran1 } \\
\text { Sabit finansal varlıklar/toplam } \\
\text { aktif }\end{array}$ & \multicolumn{2}{|l|}{$\begin{array}{l}\text { Negatif } \\
\text { İlişki yok } \\
\text { İlişki yok } \\
\text { Pozitif } \\
\text { Illişki yok } \\
\text { Negatif } \\
\text { İlişki yok }\end{array}$} \\
\hline $\begin{array}{l}\text { Karaduman } \\
\text { vd. (2010) }\end{array}$ & $\begin{array}{l}2005- \\
2008\end{array}$ & Türkiye & Panel veri analizi & $\begin{array}{l}\text { *Aktif karlılı̆̆ı } \\
\text { ATS } \\
\text { BÖS } \\
\text { SDS } \\
\text { NDS } \\
\text { Finansal kaldıraç oranı } \\
\text { Firma büyüklüğü } \\
\text { GSYIH büyüme }\end{array}$ & \multicolumn{2}{|l|}{$\begin{array}{l}\text { Negatif } \\
\text { Negatif } \\
\text { Negatif } \\
\text { Negatif } \\
\text { Negatif } \\
\text { Pozitif } \\
\text { Pozitif }\end{array}$} \\
\hline Afeef (2011) & $\begin{array}{l}2003- \\
2008\end{array}$ & Pakistan & Regresyon analizi & $\begin{array}{l}\text { *Aktif karlılı̆̆ı (RAO) } \\
\text { *Faaliyet karlılığı (FK) } \\
\text { Cari oran } \\
\text { Finansal kaldıraç oranı } \\
\text { Firma büyüklüğ̈̈ } \\
\text { Satışlarda büyüme } \\
\text { SDS } \\
\text { ATS } \\
\text { BÖS } \\
\text { NDS }\end{array}$ & $\begin{array}{l}\text { RAO } \\
\text { İlişki yok } \\
\text { İlişki yok } \\
\text { İlişki yok } \\
\text { İliskki yok } \\
\text { İlişki yok } \\
\text { İlişki yok } \\
\text { İlişki yok } \\
\text { İlişki yok }\end{array}$ & $\begin{array}{l}\text { FK } \\
\text { İlişki } \\
\text { yok } \\
\text { İlişki } \\
\text { yok } \\
\text { Pozitif } \\
\text { Illişki } \\
\text { yok } \\
\text { Negatif } \\
\text { Negatif } \\
\text { İlisski } \\
\text { yok } \\
\text { İlişki } \\
\text { yok }\end{array}$ \\
\hline $\begin{array}{l}\text { Coşkun ve } \\
\text { Kök (2011) }\end{array}$ & $\begin{array}{l}1991- \\
2005\end{array}$ & Türkiye & $\begin{array}{l}\text { Dinamik panel } \\
\text { veri analizi }\end{array}$ & $\begin{array}{l}\text { *Aktif karlılı̆̆ } 1 \\
\text { NDS } \\
\text { ATS } \\
\text { BÖS } \\
\text { SDS } \\
\text { Net çalışma sermayesi/toplam } \\
\text { aktif }\end{array}$ & $\begin{array}{l}\text { Negatif } \\
\text { Negatif } \\
\text { Pozitif } \\
\text { Negatif } \\
\text { Pozitif }\end{array}$ & \\
\hline $\begin{array}{l}\text { Sharma ve } \\
\text { Kumar } \\
\text { (2011) }\end{array}$ & $\begin{array}{l}2000- \\
2008\end{array}$ & Hindistan & & $\begin{array}{l}\text { *Aktif karlılığı } \\
\text { ATS } \\
\text { BÖS } \\
\text { SDS } \\
\text { NDS } \\
\text { Firma büyüklüğü } \\
\text { Satışlarda büyüme } \\
\text { Finansal kaldıraç oranı } \\
\text { Cari oran }\end{array}$ & $\begin{array}{l}\text { Pozitif } \\
\text { İlişki yok } \\
\text { İlişki yok } \\
\text { İlişki yok } \\
\text { Negatif } \\
\text { İlişki yok } \\
\text { İlişki yok } \\
\text { İlişki yok }\end{array}$ & \\
\hline $\begin{array}{l}\text { Dursun ve } \\
\text { Ayriçay } \\
\text { (2012) }\end{array}$ & $\begin{array}{l}1996- \\
2005\end{array}$ & Türkiye & Panel veri analizi & $\begin{array}{l}\text { *Brüt satı̧̧ karı } \\
\text { ATS } \\
\text { SDS } \\
\text { BÖS } \\
\text { NDS } \\
\text { Finansal kaldıraç oranı } \\
\text { Finansal duran varlılar oranı } \\
\text { Firma büyüklüğ̈ } \\
\end{array}$ & $\begin{array}{l}\text { İlişki yok } \\
\text { Negatif } \\
\text { Negatif } \\
\text { Negatif } \\
\text { Negatif } \\
\text { Pozitif } \\
\text { Pozitif }\end{array}$ & \\
\hline $\begin{array}{l}\text { Akoto vd. } \\
\text { (2013) }\end{array}$ & $\begin{array}{l}2005- \\
2009\end{array}$ & Gana & Panel veri analizi & $\begin{array}{l}\text { *Özsermaye karlllı̆̆ı } \\
\text { ATS } \\
\text { BÖS } \\
\text { NDS } \\
\text { Cari oran } \\
\text { Firma büyüklüğ̈̈ } \\
\text { Satışlarda büyüme }\end{array}$ & $\begin{array}{l}\text { Negatif } \\
\text { İlişki yok } \\
\text { Pozitif } \\
\text { Pozitif } \\
\text { Pozitif } \\
\text { Pozitif }\end{array}$ & \\
\hline
\end{tabular}




\begin{tabular}{|c|c|c|c|c|c|c|}
\hline $\begin{array}{l}\text { Arshad ve } \\
\text { Gondal } \\
\text { (2013) }\end{array}$ & $\begin{array}{l}2004- \\
2010\end{array}$ & $\begin{array}{l}\text { Pakistan- } \\
\text { Çimento } \\
\text { sektörü }\end{array}$ & Regresyon analizi & $\begin{array}{l}\text { *Aktif karlılığı } \\
\text { Cari oran } \\
\text { Likidite oranı } \\
\text { Net dönen varlıklar/toplam ak- } \\
\text { tifler } \\
\text { Çalışma sermayesi devir hızı } \\
\text { Stok devir hızı }\end{array}$ & \multicolumn{2}{|l|}{$\begin{array}{l}\text { Pozitif } \\
\text { Negatif } \\
\text { Pozitif } \\
\text { İlişki yok } \\
\text { İlişki yok }\end{array}$} \\
\hline $\begin{array}{l}\text { Meder Çakır } \\
\text { (2013) }\end{array}$ & $\begin{array}{l}2000- \\
2010\end{array}$ & $\begin{array}{l}\text { Türkiye- } \\
\text { İmalat sek- } \\
\text { törü firma- } \\
\text { ları }\end{array}$ & Panel veri analizi & $\begin{array}{l}\text { *Devamlı sermayenin kazanma } \\
\text { gücü } \\
\text { Aktif devir hızı } \\
\text { Kaldıraç oranı } \\
\text { NDS } \\
\text { ATS } \\
\text { SDS } \\
\text { BÖS }\end{array}$ & \multicolumn{2}{|l|}{$\begin{array}{l}\text { Pozitif } \\
\text { Pozitif } \\
\text { Pozitif } \\
\text { İlişki yok } \\
\text { Pozitif } \\
\text { Negatif }\end{array}$} \\
\hline Agha (2014) & $\begin{array}{l}1996- \\
2011\end{array}$ & Pakistan & Panel veri analizi & $\begin{array}{l}\text { *Aktif karlılığı } \\
\text { ATS } \\
\text { BÖS } \\
\text { SDS } \\
\text { Cari oran }\end{array}$ & \multicolumn{2}{|l|}{$\begin{array}{l}\text { Pozitif } \\
\text { Pozitif } \\
\text { Pozitif } \\
\text { İlişki yok }\end{array}$} \\
\hline $\begin{array}{l}\text { Enqvist vd. } \\
\text { (2014) }\end{array}$ & $\begin{array}{l}1990- \\
2008\end{array}$ & $\begin{array}{l}\text { Nasdaq } \\
\text { OMX Hel- } \\
\text { sinki firma- } \\
\text { lar1 }\end{array}$ & Regresyon analizi & $\begin{array}{l}\text { *Aktif karlılı̆̆ } \\
\text { *Büt faaliyet karlılığı } \\
\text { NDS } \\
\text { ATS } \\
\text { SDS } \\
\text { BÖS } \\
\text { Cari oran } \\
\text { Satışlarda büyüme } \\
\text { Kaldıraç oranı }\end{array}$ & $\begin{array}{l}\text { ROA } \\
\text { Negatif } \\
\text { Negatif } \\
\text { Negatif } \\
\text { Negatif } \\
\text { Pozitif } \\
\text { Negatif } \\
\text { Pozitif }\end{array}$ & $\begin{array}{l}\text { FKAR } \\
\text { Negatif } \\
\text { Negatif } \\
\text { Negatif } \\
\text { Negatif } \\
\text { Pozitif } \\
\text { Negatif } \\
\text { Negatif }\end{array}$ \\
\hline $\begin{array}{l}\text { Atmaca } \\
(2016)\end{array}$ & $\begin{array}{l}2009- \\
2015\end{array}$ & $\begin{array}{l}\text { Türkiye- } \\
\text { Kimya, } \\
\text { plastik ve } \\
\text { kauçuk iş- } \\
\text { letmeleri }\end{array}$ & $\begin{array}{l}\text { Korelasyon analizi } \\
\text { ve Panel veri ana- } \\
\text { lizi }\end{array}$ & $\begin{array}{l}\text { *Aktif karlılığı (ROA) } \\
\text { *Özsermaye karlılığ }(\mathrm{ROE}) \\
\text { ATS } \\
\text { SDS } \\
\text { BÖS } \\
\text { NDS } \\
\text { Cari oran }\end{array}$ & $\begin{array}{l}\text { ROA } \\
\text { Negatif } \\
\text { Negatif } \\
\text { Negatif } \\
\text { Pozitif } \\
\text { Pozitif }\end{array}$ & $\begin{array}{l}\text { ROE } \\
\text { Negatif } \\
\text { Pozitif } \\
\text { Negatif } \\
\text { Pozitif } \\
\text { Pozitif }\end{array}$ \\
\hline $\begin{array}{l}\text { Güldeci } \\
(2016)\end{array}$ & $\begin{array}{l}2006- \\
2015\end{array}$ & $\begin{array}{l}\text { Türkiye- } \\
\text { Gübre işlet- } \\
\text { meleri }\end{array}$ & $\begin{array}{l}\text { Çoklu doğrusal } \\
\text { regresyon analizi }\end{array}$ & $\begin{array}{l}\text { *Aktif karlılığ1 } \\
\text { ATS } \\
\text { BÖS } \\
\text { SDS } \\
\text { Aktif devir hızı } \\
\text { Cari oran } \\
\text { Nakit oran }\end{array}$ & \multicolumn{2}{|l|}{$\begin{array}{l}\text { İlişki yok } \\
\text { Negatif } \\
\text { Pozitif } \\
\text { İlişki yok } \\
\text { Pozitif } \\
\text { İlişki yok }\end{array}$} \\
\hline $\begin{array}{l}\text { Kendirli ve } \\
\text { Çankaya } \\
\text { (2016) }\end{array}$ & $\begin{array}{l}2010- \\
2014\end{array}$ & $\begin{array}{l}\text { Türkiye- } \\
\text { Turizm en- } \\
\text { deksi }\end{array}$ & $\begin{array}{l}\text { Çoklu doğrusal } \\
\text { regresyon analizi }\end{array}$ & $\begin{array}{l}\text { *Aktif karlılığı } \\
\text { ATS } \\
\text { Borçların ortalama vadesi } \\
\text { Nakit döngüsü } \\
\text { Aktif büyüklüğü } \\
\text { Satışların büyüme oranı } \\
\text { Kaldıraç oranı }\end{array}$ & \multicolumn{2}{|l|}{$\begin{array}{l}\text { Negatif } \\
\text { İlişki yok } \\
\text { Pozitif } \\
\text { Pozitif } \\
\text { İlişki yok } \\
\text { Negatif }\end{array}$} \\
\hline $\begin{array}{l}\text { Keskin ve } \\
\text { Gökalp } \\
\text { (2016) }\end{array}$ & $\begin{array}{l}2009- \\
2013\end{array}$ & $\begin{array}{l}\text { Türkiye- } \\
\text { Gida sek- } \\
\text { törü firma- } \\
\text { ları }\end{array}$ & Panel veri analizi & $\begin{array}{l}\text { *Aktif Karlılığı } \\
\text { NDS } \\
\text { ATS } \\
\text { SDS } \\
\text { BÖS } \\
\text { Cari oran } \\
\text { Firma büyüklüğü } \\
\text { Kaldıraç oranı }\end{array}$ & \multicolumn{2}{|l|}{$\begin{array}{l}\text { Negatif } \\
\text { Negatif } \\
\text { Negatif } \\
\text { Pozitif } \\
\text { Negatif } \\
\text { Pozitif } \\
\text { Negatif }\end{array}$} \\
\hline
\end{tabular}




\begin{tabular}{|c|c|c|c|c|c|c|}
\hline $\begin{array}{l}\text { Helhel ve } \\
\text { Karasakal } \\
(2017)\end{array}$ & $\begin{array}{l}2005- \\
2015\end{array}$ & $\begin{array}{l}\text { Türkiye- } \\
\text { Konaklama } \\
\text { işletmeleri }\end{array}$ & Panel veri analizi & $\begin{array}{l}\text { *Aktif karlılığı (ROA) } \\
\text { *Özsermaye karlılığı (ROE) } \\
\text { Asit-test oranı } \\
\text { Alacak devir hızı } \\
\text { Stok devir hızı } \\
\text { Cari oran } \\
\text { Nakit oranı } \\
\text { Aktif devir hızı } \\
\text { Kısa vadeli borç oranı } \\
\text { Net işletme sermayesi oranı } \\
\text { İşletme sermayesi devir hızı } \\
\text { Kısa vadeli borç/top. borç oranı }\end{array}$ & $\begin{array}{l}* \text { ROA } \\
\text { Pozitif } \\
\text { Pozitif } \\
\text { Negatif } \\
\text { Negatif } \\
\text { Pozitif } \\
\text { Pozitif } \\
\text { Negatif } \\
\text { Negatif } \\
\text { Pozitif } \\
\text { Pozitif }\end{array}$ & $\begin{array}{l}\text { *ROE } \\
\text { Negatif } \\
\text { Pozitif } \\
\text { Negatif } \\
\text { Negatif } \\
\text { Negatif } \\
\text { Pozitif } \\
\text { Pozitif } \\
\text { Negatif } \\
\text { Pozitif } \\
\text { Negatif }\end{array}$ \\
\hline $\begin{array}{l}\text { Köse İçige- } \\
\text { çen ve Karaş } \\
(2017)\end{array}$ & $\begin{array}{l}2012- \\
2016\end{array}$ & $\begin{array}{l}\text { Türkiye- } \\
\text { Perakende } \\
\text { ticaret işlet- } \\
\text { meleri }\end{array}$ & Panel veri analizi & $\begin{array}{l}\text { *Aktif Karlılığı } \\
\text { NDS } \\
\text { SDS } \\
\text { ATS } \\
\text { BÖS } \\
\text { Cari oran } \\
\text { Pazar payı } \\
\text { Kaldıraç oranı }\end{array}$ & $\begin{array}{l}\text { İlişki yok } \\
\text { İlişki yok } \\
\text { İlişki yok } \\
\text { İlişki yok } \\
\text { İlişki yok } \\
\text { İlişki yok } \\
\text { Negatif }\end{array}$ & \\
\hline
\end{tabular}

\section{Metodoloji}

\subsection{Araştırmanın amacı ve kapsamı}

Bu çalışmanın temel amacı, BİST'de faaliyet gösteren turizm firmaları özelinde çalışma sermayesi etkinliğinin firma karlılığ üzerine olan etkisinin 2008 krizi sonrası dönem için incelenmesidir. Çalışma 2011:12-2017:12 döneminde Türkiye'de turizm sektöründe faaliyet gösteren, BİST'e kote olan ve verilerine düzenli olarak ulaşılabilen 6 turizm firmasına ilişkin altı aylık verileri kapsamaktadır. Çalışmaya dahil edilen turizm firmalarının verileri Kamu Aydınlatma Platformu (KAP)'nun web sayfasindan ve Financial Information News Network (Finnet) mali analiz veri tabanından elde edilmiştir. Çalışmada, çalışma sermayesinin temel göstergesi olarak kabul edilen nakit dönüşüm süresi (NDS) ve bileşenleri olan stok devir süresi (SDS), alacak tahsil süresi (ATS) ve borçların ödenme süresi (BÖS) ayrı modellerde bağımsız değişken olarak ele alınarak firma karlılığ üzerinde nakit dönüşüm süresi ve bileşenlerinin etkileri ayrı ayrı incelenmiştir. Analizler çalışmanın amacına uygun olarak nakit dönüşüm süresinin bağımsız değişken olarak yer aldığı Model 1, alacak tahsil süresinin bağımsız değişken olarak yer aldığ 1 Model 2, borçların ödenme süresinin bağımsız değişken olarak yer aldığı Model 3 ve stok devir süresinin bağımsız değişken olarak yer aldığ 1 Model 4 olmak üzere dört ayrı model oluşturularak gerçekleştirilmiştir. Çalışmada verilerinden faydalanılan turizm firmalarının listesi Tablo 2'de verilmiştir.

Tablo 2. Araştırmaya dâhil edilen firmalar

\begin{tabular}{|c|c|c|}
\hline $\begin{array}{l}\text { Firma } \\
\text { Kodu }\end{array}$ & Firma Adı & $\begin{array}{l}\text { Faaliyet Alanı / } \\
\text { Sektör }\end{array}$ \\
\hline AYCES & $\begin{array}{l}\text { ALTIN YUNUS } \\
\text { ÇEŞME TURISTIK } \\
\text { TESISLER A.Ş. }\end{array}$ & $\begin{array}{l}\text { Toptan ve pera- } \\
\text { kende ticaret, otel } \\
\text { ve lokantalar / Lo- } \\
\text { kanta ve Oteller }\end{array}$ \\
\hline ETILR & $\begin{array}{l}\text { ETILER GIDA VE } \\
\text { TİCARİ YATIRIM- } \\
\text { LAR SANAYİ VE } \\
\text { TİCARET A.Ş. }\end{array}$ & $\begin{array}{l}\text { Toptan ve pera- } \\
\text { kende ticaret, otel } \\
\text { ve lokantalar / Lo- } \\
\text { kanta ve Oteller }\end{array}$ \\
\hline MAALT & $\begin{array}{l}\text { MARMARIS AL- } \\
\text { TINYUNUS TU- } \\
\text { RISTIIK TESISLER } \\
\text { A.Ş. }\end{array}$ & $\begin{array}{l}\text { Toptan ve pera- } \\
\text { kende ticaret, otel } \\
\text { ve lokantalar / Lo- } \\
\text { kanta ve Oteller }\end{array}$ \\
\hline PKENT & $\begin{array}{l}\text { PETROKENT TU- } \\
\text { RIZM A.Ş. }\end{array}$ & $\begin{array}{l}\text { Toptan ve pera- } \\
\text { kende ticaret, otel } \\
\text { ve lokantalar / Lo- } \\
\text { kanta ve Oteller }\end{array}$ \\
\hline TEKTU & $\begin{array}{l}\text { TEK-ART İNŞAAT } \\
\text { TİCARET TURIZM } \\
\text { SANAYI VE YATI- } \\
\text { RIMLAR A.Ş. }\end{array}$ & $\begin{array}{l}\text { Toptan ve pera- } \\
\text { kende ticaret, otel } \\
\text { ve lokantalar/Lo- } \\
\text { kanta ve Oteller }\end{array}$ \\
\hline UTPYA & $\begin{array}{l}\text { UTOPYA TURIZM } \\
\text { İNŞAAT ISSLET- } \\
\text { MECILIK TICA- } \\
\text { RET A.Ş. }\end{array}$ & $\begin{array}{l}\text { Toptan ve pera- } \\
\text { kende ticaret, otel } \\
\text { ve lokantalar / Lo- } \\
\text { kanta ve Oteller }\end{array}$ \\
\hline
\end{tabular}




\subsection{Araştırmanın veri seti ve yöntemi}

Araştırma kapsamında 2011:12-2017:12 döneminde Türkiye'de faaliyet gösteren 6 turizm firmasına ilişkin veriler kullanılarak nakit dönüşüm süresi ve bileşenlerinin ayrı modellerde bağımsız değişkenler olarak yer aldıkları dört farklı model oluşturulmuştur. Araştırmanın amacı doğrultusunda, tüm modellerde bağımlı değişken olarak firmaların faaliyet karlılığı oranı kullanılmıştır. Çalışma sermayesi ile ilgili literatürde sıklıkla kullanılan nakit dönüşüm süresi, alacak tahsil süresi, borçların ödenme süresi ve stok devir süresi ise farklı modellerde bağımsız değişken olarak kullanılmışlardır. Ayrıca faaliyet karlılığı ile çalışma sermayesi arasındaki ilişkiyi inceleyen çalışmalarda sıklıkla kullanılan diğer değişkenler olan cari oran, finansal kaldıraç oranı ve satışlarda büyüme oranı da modellere bağımsız değişken olarak eklenmiştir. İlgili literatür doğrultusunda çalışmaya daha fazla seçilmiş finansal oran bağımsız değişken olarak eklenmek istenmiştir. Fakat finansal oranlar arasında gözlemlenen yüksek korelasyon, çoklu doğrusal bağlantı sorununa sebep olacağından bazı finansal oranlar çalışma kapsamından çıkarılmıştır. Çalışmada bağımsız değişken olarak kullanılan finansal oranlara ilişkin detaylı bilgiler ve formüller Tablo 3’te verilmiştir.

Tablo 3. Çalışmada Kullanılan Bağımlı ve Bağımsız Değişkenler

\begin{tabular}{l|l|l|l}
\hline & Oran Grubu & Oran & Oranın Hesaplanışı \\
\hline $\begin{array}{l}\text { Bağımlı } \\
\text { Değişken }\end{array}$ & Faaliyet Karlılık Oranı & FKAR & (Satış Gelirleri-Satışların Maliyeti)/Toplam Aktifler \\
\hline \multirow{4}{*}{$\begin{array}{l}\text { Bağımsız } \\
\text { Değişkenler }\end{array}$} & Nakit Dönüşüm Süresi & NDS & SDS+ATS-BÖS \\
\cline { 2 - 4 } & Alacak Tahsil Süresi & ATS & $360 /($ Satışların Gelirleri/Toplam Ticari Alacaklar) \\
\cline { 2 - 4 } & Stok Devir Süresi & SDS & $360 /($ Satışların Maliyeti/Stoklar) \\
\cline { 2 - 4 } & Borçların Ödenme Süresi & BÖS & $360 /($ Satışların Maliyeti/Kısa Vadeli Yabancı Kaynaklar) \\
\cline { 2 - 4 } & Cari Oran & CO & Dönen Varlıklar/Kısa Vadeli Yabancı Kaynaklar \\
\cline { 2 - 4 } & Kaldıraç Oranı & KO & Toplam Yabancı Kaynak / Toplam Aktifler \\
\cline { 2 - 4 } & Satışlarda Büyüme Oranı & SATIŞ & (Cari Dönem Satışlar-Önceki Dönem Satışlar)/Önceki Dönem Satışlar \\
\hline
\end{tabular}

Çalışma kapsamında oluşturulan dört modelde de temel olarak çalışma sermayesi yönetimi ile firma karlılığı arasındaki ilişki incelenmiştir. Dolayısıyla dört model için de sinanan hipotezler benzerdir. Modeller arasındaki farklılık içerdikleri çalışma sermayesi yönetimi temsilcisi bağımsız değişkenlerdir. Bu bağlamda dört modelde de s1nanan hipotez aşağıdaki gibi ifade edilebilir.

$\mathrm{H}_{0}$ : Çalışma sermayesi yönetimi ile faaliyet karlılığı arasında ilişki yoktur.

$\mathrm{H}_{1}$ : Çalışma sermayesi yönetimi ile faaliyet karlılığı arasında ilişki vardır.

Çalışmada turizm firmalarının karlılıkları ile çalışma sermayesi yönetimi arasındaki ilişki panel veri analizi ile incelenmiştir. Yatay kesit veriler ile zaman serisi verilerinin bir arada ele alınması ile oluşturulan veri türlerine panel veri denmektedir (Tatoğlu, 2013: 2). Çalışma kapsamında oluşturulan veri setleri 6 birim ve 13 döneme panel veri setleridir.
Panel veriler sadece yatay kesit veya sadece zaman serisine kıyasla çeşitli avantaj ve dezavantajlara sahiptirler. Panel verilerin sağladığı çeşitli avantajlar veya faydalar aşağıdaki gibi sıralanabilir (Hsiao, 2006: 3-8; Baltagi, 2014: 6-8);

- Panel verilerinin kullanımı bireysel heterojenliği kontrol etmemizi sağlar.

- Panel verilerin kullanımı daha bilgilendirici veriler, değişkenler arasında daha az çoklu doğrusal bağlantı, daha fazla serbestlik derecesi ve daha fazla verimlilik sağlar.

- Panel verilerin kullanımı uyum dinamiği çalışmalarında daha iyi sonuçlar verir.

- Panel veriler, saf yatay kesit veya zaman serisi verilerinde saptanamayan etkilerin tanımlanması ve ölçülmesi için daha uygundur.

- Panel veri modelleri, saf yatay kesit veya zaman serisi verilerinden daha karmaşık davranış 
modelleri oluşturup test etmemize olanak sağlar.

- Firmalar ve hane halkları üzerinden toplanan mikro panel veriler, makro düzeyde ölçülen benzer değişkenlerden daha doğru ve sapmasız çıkarımlar sağlayabilir. Panel verilerde yatay kesit verilere kıyasla daha uzun zaman boyutu barındırıldığından firma ya da bireyler üzerinden veri toplanma sonucunda ortaya çıkan yanl1lıklar azaltılabilir ya da ortadan kaldırılabilir.

- Makro panel veriler ise, daha uzun zaman serilerine sahiptirler ve panel birim kök testleri standart asimptotik dağılımlara sahiptir ve zaman serileri analizinde olduğu gibi birim kök testlerinde karşılaşılan standart dışı dağılım problemi ile karşılaşılmamaktadır.

Panel verilerin sahip olduğu çeşitli dezavantajlar veya sınırlılıklar aşağıdaki gibi sıralanabilir (Baltagi, 2014: 8-11);

- Panel veriler saf yatay kesit veya zaman serisi verilerine göre veri toplama ve tasarım süreci açısından daha zorludur.

- Panel verilerde açık ve net olmayan sorular veya hafiza sorunları gibi sorunlar nedeniyle ölçüm bozukluğu hataları ile karşılaşılabilir.

- Mikro panel verilerde kisa zaman boyutu ve yüksek yatay kesit boyutu söz konusudur. $\mathrm{Bu}$ durum, asimptotik argümanların sonsuz eğilim gösteren yatay kesit sayısına duyarlı bir şekilde ortaya çıkması sonucunu doğurmaktadır.

- Makro panel verilerde ise uzun zaman boyutu ve kısa yatay kesit boyutu söz konusudur. Bu tür panellerde birimler, firmalar veya ülkeler arasındaki bağımlılık olarak ifade edilen yatay kesit bağımlılı̆̆ının dikkate alınmaması yanıltıcı çıkarımlara yönlendirebilir.

Çalışma kapsamında oluşturulan modeller aynı temele dayanmaktadır. Her dört modelde de yer alan bağımlı değişken faaliyet karlılığıdır (FKAR). Modeller, bağımsız değişken olarak yer alan nakit dönüşüm süresi ve bileşenlerine göre farklılık göstermektedir. Çalışma kapsamında oluşturulan panel regresyon modelleri aşağıdaki gibi ifade edilebilir.

$$
\begin{aligned}
& F K A R_{i t}=\beta_{0}+\beta_{1} N D S_{i t}+\beta_{2} C O_{i t}+ \\
& \beta_{3} \text { FİNKAL } L_{i t}+\beta_{4} \text { SATIS }_{i t}+u_{i t} \\
& F K A R_{i t}=\beta_{0}+\beta_{1} A T S_{i t}+\beta_{2} C O_{i t}+ \\
& \beta_{3} F_{\mathrm{I} N K A L_{i t}}+\beta_{4} \text { SATISS }_{i t}+u_{i t} \\
& F K A R_{i t}=\beta_{0}+\beta_{1} B O ̈ S_{i t}+\beta_{2} C O_{i t}+ \\
& \beta_{3} F_{\dot{I} N K A L_{i t}}+\beta_{4} \text { SATIŞ }_{i t}+u_{i t} \\
& F K A R_{i t}=\beta_{0}+\beta_{1} S D S_{i t}+\beta_{2} C O_{i t}+ \\
& \beta_{3} \text { FINNKAL }_{i t}+\beta_{4} \text { SATIŞ }_{i t}+u_{i t}
\end{aligned}
$$

Modelde, FKAR $_{\text {it }}$ turizm firmalarının faaliyet karlılıklarını, $\beta_{0}$ sabit değişkeni, $\beta_{\mathrm{n}}$ değişkenlere ait eğim katsayısını, i ve t indisleri ise değişkenlerin her firma ve döneme ait değer içerdiklerini ifade etmektedir.

Panel veri analiz yöntemi ile kurulacak modellerde bireyler arası etkiler, zaman etkileri ve eşanlı birim ve zaman etkilerine göre uygulanabilecek modeller genel olarak katsayılarının sabit veya rassal varsayılmasına bağlı olarak; Havuz Modeli, Sabit Etkiler Modeli ve Rassal Etkiler Modeli olmak üzere üç farklı şekilde sınıflandırılabilir. Sabit Etkiler Modeli, belirli bir birey, firma veya ülke setine odaklanma ve sonuçların bu birey, firma veya ülkelerin davranışlarıyla sınırlı olması durumunda; Rasssal Etkiler Modeli ise, bireyler, firmalar veya ülkelerin rasgele geniş bir evrenden seçilmesi durumunda uygun olan bir modeldir (Baltagi, 2014: 14-20). Havuz Modeli ise, panelde yer alan tüm yatay kesitlerin aynı olduğu ya da aralarında bir fark bulunmadığının varsayılması durumunda uygun bir modelidir ve bu durum çeşitli testler ile tespit edilmeye çalışılır. Çalışmada kapsamında oluşturulan dört veri setinde de Türkiye'de 2011:12-2017:12 döneminde faaliyet gösteren 6 turizm yatay kesitler olarak yer almaktadır. Dolayısıyla belirli bir firma setine odaklanma durumu geçerlidir ve panel veri analizinde Sabit Etkiler Modeli'nin kullanılması uygun görülmüştür. Modelde grup (yatay kesit), zaman ve her iki boyutta sabit etkiler olup olmadığ $\mathrm{F}$ Test kullanılarak incelenmiştir.

Panel regresyon analizine geçmeden önce s1nanmas1 gereken bazı varsayımlar mevcuttur. $\mathrm{Bu}$ varsayımlar; bağımsız değişkenler arasında yüksek korelasyon olmasını ifade eden çoklu doğrusal 
bağlant1 (multi-collinearity)'nın olmaması, serilerin durağan olması (birim kök bulunmaması), modellerde yer alan birimlerin kendi aralarında ilişkili olmaları durumunu ifade eden yatay kesit bağımlılı̆̆ının (cross-sectional dependence) olmaması, kısaca hata terimleri arasındaki ilişki olarak tanımlanabilecek otokorelasyonun olmaması ve değişen varyans (heretoskedasite) olmaması gibi varsayımlardır (Ün, 2015: 71).

Uzun yatay kesit boyutuna ve kisa zaman boyutuna sahip paneller mikro paneller olarak adlandırılmaktadır. Mikro paneller minimum 2 dönem ve maksimum 10-20 döneme sahip panellerdir. Kisa veya orta yatay kesit boyutuna ve uzun zaman boyutuna sahip paneller ise makro paneller olarak adlandırılmaktadır. Makro paneller en az 720 birey, firma veya ülkeyi ve en az 20-60 dönemi kapsayan panellerdir. Mikro ve makro panellere farklı ekonometrik işlemler uygulanır. Mikro paneller uzun $\mathrm{N}$ ve sabit $\mathrm{T}$ boyutu gerektirirken makro paneller uzun $\mathrm{N}$ ve uzun $\mathrm{T}$ boyutuna sahip olabilirler. Uzun zaman boyutlarına sahip olan makro paneller ile yapılan çalışmalarda zaman serilerinde durağanlık varsayımının sağlanması gerekmektedir. Mikro paneller ile yapılan çalışmalarda ise zaman boyutu kısa olduğundan durağanl1k varsayımının sağlanması gerekmemektedir. Makro paneller ile yapılan çalışmalarda sağlanmas1 gereken diğer bir varsayım ise yatay kesit bağımlılı̆̆ının olmaması varsayımıdır. Mikro panellerle yapılan çalışmalarda ise yatay kesit bağımlılığının olmaması varsayımının sağlanması gerekmemektedir (Baltagi, 2014: 1). Bu çalışma kapsaminda oluşturulan modeller 13 dönemlik zaman boyutuna ve 6 birimlik yatay kesit boyutuna sahip olduğundan makro panel yaklaşımı ile panel regresyon analizi gerçekleştirilmiştir. Diğer bir ifadeyle değişkenlerde yatay kesit bağımlılığı ve durağanlık gibi varsayımlar dikkate alınarak analiz gerçekleştirilmiştir.

\section{Araştırmanın bulguları}

Panel veri analizinde tahminleme yapılmadan önce sinanması gereken varsayımlardan biri olan çoklu doğrusal bağlantı sorunu, regresyon analizlerinde istenmeyen bir durumu; bağımsız değişkenler arasındaki yüksek korelasyonu ifade eder (Gujarati, 2004: 341-386). Çoklu doğrusal bağlantı sorununa sebep olabilecek bir değişkenin olup olmadığının belirlenebilmesi için çeşitli yöntemler uygulanabilmekle beraber bu çalışmada, Varyans Artırıcı Faktör (Variance Inflation Factor-VIF) yönteminden faydalanılmıştır. VIF yönteminde; çalışmada kurulan modellerdeki bağıms1z değişkenlerin her biri için, bu değişkenlerin kendi aralarında sırayla birinin bağımlı ve diğerlerinin bağımsız değişkenler şeklinde yer aldığı regresyon modellerinin tahmininden elde edilen $R^{2}$ değerleri kullanılarak, 1/(1- $\left.\mathrm{R}^{2}\right)$ formülü ile VIF değerleri hesaplanmıştır (O'Brien, 2007: 673675). VIF değerinin 4'e eşit veya 4'den büyük olmas1 durumunda bu regresyon modellerinde yer alan bağımlı değişkene ilişkin anlamlı çoklu doğrusal bağlantı sorunundan söz edilir. '4' olan sınır değeri bazı araştırmacılar için ' 5 ' veya ' 10 ' olarak kabul edilmektedir (Açıkgöz vd., 2015: 433). Modellerde yer alan bağımsız değişkenlere ilişkin VIF değerleri Tablo 4’te verilmiştir.

Tablo 4. Çalışmada Kullanılan Değişkenlere Ait VIF Değerleri

\begin{tabular}{c|cc|cc|cc|cc}
\hline & \multicolumn{2}{|c|}{ NDS Modeli } & \multicolumn{2}{c|}{ ATS Modeli } & \multicolumn{2}{c|}{ BÖS Modeli } & \multicolumn{2}{c}{ SDS Modeli } \\
Değişkenler & $\mathbf{R}^{2}$ & VIF Değeri & $\mathbf{R}^{2}$ & VIF Değeri & $\mathbf{R}^{2}$ & VIF Değeri & $\mathbf{R}^{2}$ & VIF Değeri \\
\hline ATS & - & - & 0.033 & 1.034126163 & - & - & - & - \\
BÖS & - & - & - & - & 0.179 & 1.218026797 & - & - \\
SDS & - & - & - & - & - & - & 0.269 & 1.367989056 \\
NDS & 0.192 & 1.237623762 & - & - & - & - & - & - \\
CO & 0.017 & 1.017293998 & 0.017 & 1.017293998 & 0.071 & 1.076426265 & 0.016 & 1.016260163 \\
KO & 0.197 & 1.245330012 & 0.037 & 1.038421599 & 0.134 & 1.154734411 & 0.274 & 1.377410468 \\
SATIŞ & 0.020 & 1.020408163 & 0.02 & 1.020408163 & 0.022 & 1.022494888 & 0.019 & 1.019367992 \\
\hline
\end{tabular}


Tablo 4 incelendiğinde, dört modelde de 4'ün üzerinde VIF değerine sahip bir değişkenin bulunmadığı görülmektedir. Dolayısıyla, VIF analizi sonuçlarına göre dört model için de çoklu doğrusal bağlantı sorunu ile karşılaşılmayacağ1 söylenebilir.

Zaman serilerinin kullanıldığı regresyon modellerinde her bir değişkene ait serinin durağan olması gerekmektedir. Durağan serilerde, zaman içerisinde şoklar meydana gelse bile değerler ortalamaya dönebilmekte, diğer bir deyişle uzun dönemde dalgalanmalar olsa bile ortalama korunmaktadır (Gujarati, 2004: 798). Uygulanacak birim kök testinin türüne karar verebilmek için panel veri setinde yatay kesit bağımlılığının bulunup bulunmadığ 1 ve panelin homojen olup olmadığının incelenmesi gerekmektedir. Yatay kesit bağıml1lığı, birimlerin kendi aralarında ilişkili olmaları durumunu ifade eder. Diğer bir deyişle yatay kesit bağımlılığ 1 , piyasada meydana gelen bir şoktan firmaların aynı derecede etkilenip etkilenmediklerini ile ilgilidir. Serilerde yatay kesit bağımlılı̆̆ olup olmamasina göre, serilere uygulanacak birim kök testleri farklılık göstermektedir. Serilerde yatay kesit bağımlılığının olmaması durumunda serilerde durağanlığın yatay kesit bağımlılığını dikkate almayan (birinci nesil) birim kök testleri ile, serilerde yatay kesit bağımlılığının olması durumunda ise serilerde durağanlık yatay kesit bağım11lığını dikkate alan (ikinci nesil) birim kök testleri ile incelenmektedir. Serilerde yatay kesit bağıml1lığının olmaması durumunda kullanılacak birim kök testleri serilerin homojen veya heretojen özellik göstermelerine göre iki gruba ayrılmaktadır. $\mathrm{Bu}$ bağlamda, serilerde durağanlık sinaması için kullanılacak birim kök testi seride yatay kesit bağımlılığının olup olmamasına ve serinin homojen veya heterojen özellik göstermesine göre değişmektedir. Bu çalışmada serilerde yatay kesit bağımlılığı olup olmadığı Pesaran, Ullah ve Yagamata'nın 2008'de geliştirdikleri LMadj. testi ile serilerin homojen özellik gösterip göstermedikleri ise Pesaran ve Yagamata'nın 2008'de geliştirdikleri Delta ve Delta adj. (adjusted) testler ile incelenmiştir. Çalışmada kullanılan değişkenlere ilişkin yatay kesit bağımlılığı ve homojenite testleri sonuçları Tablo 5'te yer almaktadır.
Tablo 5'te yer alan LMadj. CD (cross-sectional dependence) yatay kesit bağımlılığ testi sonuçları incelendiğinde değişkenlere ait olasılık değerlerinin 0.05 'ten büyük olduğu görülmektedir. $\mathrm{Bu}$ durumda değişkenlerde yatay kesit bağımlılığının olmadığı söylenebilir. Değişkenlere ilişkin serilerin homojen olup olmadıklarını tespit etmek için yapılan Delta testlerinin sonuçlarını incelendiğinde ATS ve SATIŞ değişkenlerine ilişkin serilerin her iki teste göre de homojen olduğu, diğer serilerin ise her iki teste göre de heterojen olduğu tespit edilmiştir. Bu bağlamda serilerde durağanlık sınaması yapılırken yatay kesit bağımlılı̆̆ ve homojenite testlerinin sonuçları dikkate alınarak ATS ve SATIŞ değişkenleri için yatay kesit bağımlılığını dikkate almayan (birinci nesil) ve homojen panellere uygulanabilen bir birim kök testi olan Levin, Lin ve Chu (2002)'nun geliştirdiği birim kök testi, diğer değişkenler için ise yatay kesit bağımlılığını dikkate almayan (birinci nesil) ve heterojen panellere uygulanabilen Im, Pesaran ve Shin (2003)'in geliştirdiği birim kök testi kullanılmıştır. Değişkenlere ilişkin panel birim kök testi sonuçları Tablo 6'da verilmiştir.

Tablo 6 incelendiğinde tüm değişkenlerin düzeyde durağan oldukları görülmektedir. $\mathrm{Bu}$ durumda oluşturulan panel veri modelleri için birim kök sorununun olmadığ 1 söylenebilir.

Veri setinde sabit etkilerin yatay kesit boyutunda, zaman boyutunda veya her iki boyutta birden gözlenip gözlenmediği $\mathrm{F}$ testi ile incelenmiştir. F testinde havuz modeli ile sabit etkiler modeli arasında bir seçim yapılması söz konusudur. F testinde genel olarak verilerin, birimlere göre farkl1lığ 1 test edilmektedir. Veri birimlere göre farklılık göstermiyorsa havuz modeli, farkl11ı gösteriyorsa sabit etkiler modeli tercih edilir (Tatoğlu, 2013: 164). Söz konusu farklılıkların yatay kesit boyutunda olup olmadığı F-Grup Sabit Etkiler Testi, zaman boyutunda olup olmadığ F-Zaman Sabit Etkiler Testi ve her iki boyutta birden olup olmadığı F-İki Yönlü Sabit Etkiler Testi ile incelenmiştir. Panel regresyon analizine geçilmeden önce test edilmesi gereken ve modelde hata terimlerinin birimler içerisinde ve birimlere göre sabit olmaması durumunu ifade eden değişen varyans sorunu Breusch-Pagan (1979) LMh testiyle, modellerde 
hata terimleri arasında var olan ilișki olarak ifade edilen otokorelasyon sorununun olup olmadığ 1 Baltagi ve Lee (1995) LMp ve Born ve Breitung
(2016) LMp* testleriyle incelenmiş̧ir. F, değişen varyans ve otokorelasyon testlerine ilişkin sonuçlar Tablo 7'de yer almaktadır.

Tablo 5. Yatay Kesit Bağımlılı̆̆ı ve Honojenite testlerine ilişkin sonuçları

\begin{tabular}{|c|c|c|c|c|c|c|c|c|}
\hline \multirow{3}{*}{ Değişkenler } & \multirow{2}{*}{\multicolumn{2}{|c|}{$\begin{array}{c}\text { Yatar Kesit Bağımlıı̆ı̆ı Testi } \\
\text { LMadj CD Test }\end{array}$}} & \multirow{3}{*}{$\begin{array}{c}\text { YKB } \\
\text { Testi So- } \\
\text { nucu }\end{array}$} & \multicolumn{4}{|c|}{ Homojenite Testleri } & \multirow{3}{*}{$\begin{array}{l}\text { Homojenite } \\
\text { Testi So- } \\
\text { nucu }\end{array}$} \\
\hline & & & & \multicolumn{2}{|c|}{ Delta tilde } & \multicolumn{2}{|c|}{ Delta tilde adj } & \\
\hline & İstatistik & Olasilık & & İstatis- & Olasılık & İsta- & Olasılık & \\
\hline ATS & -0.465 & 0.679 & YOK & 0.404 & 0.343 & 0.460 & 0.323 & Homoien \\
\hline BÖS & -0.374 & 0.646 & YOK & 4.506 & 0.000 & 5.138 & 0.000 & Heterojen \\
\hline SDS & -1.179 & 0.957 & YOK & 2.206 & 0.014 & 2.515 & 0.006 & Heterojen \\
\hline NDS & -0.486 & 0.687 & YOK & 1.703 & 0.044 & 1.941 & 0.026 & Heterojen \\
\hline FKAR & 0.056 & 0.478 & YOK & 6.894 & 0.000 & 7.60 & 0.000 & Heterojen \\
\hline $\mathrm{CO}$ & 0.236 & 0.407 & YOK & 1.929 & 0.027 & 2.200 & 0.014 & Heterojen \\
\hline KO & 0.932 & 0.176 & YOK & 2.002 & 0.023 & 2.283 & 0.011 & Heterojen \\
\hline SATIȘ & 0.280 & 0.390 & YOK & 0.488 & 0.313 & 0.556 & 0.289 & Homojen \\
\hline
\end{tabular}

Tablo 6. Birim Kök Testlerine İlişkin Sonuçları

\begin{tabular}{|c|c|c|c|c|c|}
\hline & & \multicolumn{4}{|c|}{ Birim Kök Seviyesi } \\
\hline \multirow[b]{2}{*}{ Değişkenler } & \multirow[b]{2}{*}{ İstatistik Olasılık } & \multicolumn{2}{|c|}{ Sabitli } & \multicolumn{2}{|c|}{ Sabitli ve Trendli } \\
\hline & & $\begin{array}{l}\text { Levin, Lin \& } \\
\text { Chu t }\end{array}$ & $\begin{array}{l}\text { Im, Pesaran } \\
\text { and Shin } \\
\text { W-stat }\end{array}$ & $\begin{array}{l}\text { Levin, Lin \& } \\
\text { Chu t }\end{array}$ & $\begin{array}{l}\text { Im, Pesaran } \\
\text { and Shin } \\
\text { W-stat }\end{array}$ \\
\hline \multirow{2}{*}{ ATS } & İstatistik & -8.98880 & & -10.4896 & \\
\hline & Olasılık & $0.0000 * * *$ & & $0.0000 * * *$ & \\
\hline \multirow{2}{*}{ BÖS } & İstatistik & & -2.13946 & & -7.51187 \\
\hline & Olasılık & & $0.0162 * *$ & & $0.0000 * * *$ \\
\hline \multirow{2}{*}{ SDS } & İstatistik & & -2.79218 & & -9.18201 \\
\hline & Olasılık & & $0.0026^{* * *}$ & & $0.0003 * * *$ \\
\hline \multirow{2}{*}{ NDS } & İstatistik & & -13.8035 & & -12.7046 \\
\hline & Olasılık & & $0.0000^{* * *}$ & & $0.0000 * * *$ \\
\hline \multirow{2}{*}{ FKAR } & İstatistik & & -3.59878 & & -10.8336 \\
\hline & Olasılik & & $0.0002 * * *$ & & $0.0000 * * *$ \\
\hline \multirow{2}{*}{$\mathrm{CO}$} & İstatistik & & -19.2295 & & -18.9139 \\
\hline & Olasılık & & $0.0000 * * *$ & & $0.0000 * * *$ \\
\hline \multirow{2}{*}{$\mathrm{KO}$} & İstatistik & & -16.1280 & & -16.0440 \\
\hline & Olasılık & & $0.0000^{* * *}$ & & $0.0000 * * *$ \\
\hline \multirow{3}{*}{ SATIŞ } & İstatistik & -27.8181 & & -25.7204 & \\
\hline & Olasılık & $0.0000^{* * *}$ & & $0.0000^{* * *}$ & \\
\hline & Olasılık & $0.0000 * * *$ & & $0.0000 * * *$ & \\
\hline
\end{tabular}

Not: Testlerdeki gecikme uzunlukları Schwarz Bilgi Kriteri’ne (Schwarz Info Criterion) göre belirlenmiştir. *** işareti \%1 ve ** işareti $\% 5$ anlamlılık düzeyini göstermektedir.

Tablo 7'de yer alan F-test sonuçlarına göre, dört model için de hem F-Grup Sabit Etkiler hem F-Zaman Sabit Etkiler hem de F-İki Yönlü Sabit Etkiler testlerine ilişkin p-değerleri 0.05 kritik değerinden yüksek gerçekleşmiştir. Dolayısıyla dört model için de yatay kesit boyutunda, zaman boyutunda veya hem yatay kesit ve hem zaman boyutunda sabit etkilerden söz etmek mümkün değildir.
LMh değişen varyans testi sonuçları incelendiğinde dört model için de olasılık değerleri 0.05 kritik değerinden düşük olduğundan modellerde değişen varyans sorununun olduğu tespit edilmiştir. LMp ve LMp* otokorelasyon testleri sonuçları incelendiğinde, dört model için de olasılık değerleri 0.05 kritik değerinden düşük olduğundan modellerde otokorelasyon sorununun olduğu tespit edilmiştir. Panel regresyon analizlerinde tahminleme 
yapılırken, değişen varyans ve otokorelasyon gibi sorunların giderilmesinde kullanılan yöntemlerden biri de White düzeltmesi olarak da bilinen White'ın Dönem Kovaryans Katsayısı (White Period Coefficient Covariance) yöntemidir (Kork- maz vd., 2010: 102). Bu çalışmada da panel regresyon modeli tahmin edilirken değişen varyans sorunu, White Dönem Kovaryans Katsayısı yöntemiyle standart hatalar düzeltilerek giderilmeye çalışılmıştır. Modellere ilişkin panel veri analizi sonuçları Tablo 8'de verilmiştir.

Tablo 7. F-Test, Değişen Varyans ve Otokorelasyon Testlerine İlişkin Sonuçlar

\begin{tabular}{|c|c|c|c|c|c|c|c|c|}
\hline \multirow[b]{2}{*}{ Test } & \multicolumn{2}{|c|}{ Model 1} & \multicolumn{2}{|c|}{ Model 2} & \multicolumn{2}{|c|}{ Model 3} & \multicolumn{2}{|c|}{ Model 4} \\
\hline & İstatistik & p-Değeri & İstatistik & p-Değeri & İstatistik & p-Değeri & İstatistik & p-Değeri \\
\hline F-Test & & & & & & & & \\
\hline F-Grup Sabit Etkiler & 1.573749 & 0.182472 & 1.951708 & 0.100197 & 2.105049 & 0.078210 & 1.533235 & 0.194322 \\
\hline F-Zaman Sabit Etkiler & 1.134974 & 0.351922 & 1.176459 & 0.322177 & 0.893120 & 0.558916 & 1.069533 & 0.402581 \\
\hline F-İki Yönlü Sabit Etkiler & 1.198475 & 0.295996 & 1.375292 & 0.184207 & 1.220347 & 0.279856 & 1.131933 & 0.349224 \\
\hline Değișen Varyans Testi & & & & & & & & \\
\hline LMh_Sabit Etkiler & 77.84122 & 0.000000 & 75.91034 & 0.000000 & 72.61619 & 0.000000 & 82.21239 & 0.000000 \\
\hline Otokorelasyon Testleri & & & & & & & & \\
\hline LMp-İstatistiği & 5.446934 & 0.000000 & 5.245438 & 0.022004 & 3.907357 & 0.048075 & 6.000840 & 0.014299 \\
\hline LMp*-İstatistiği & 9.433125 & 0.000000 & 9.164725 & 0.002467 & 7.347405 & 0.006716 & 10.16519 & 0.001431 \\
\hline
\end{tabular}

Tablo 8. Modellere ilişkin panel veri analizi sonuçları

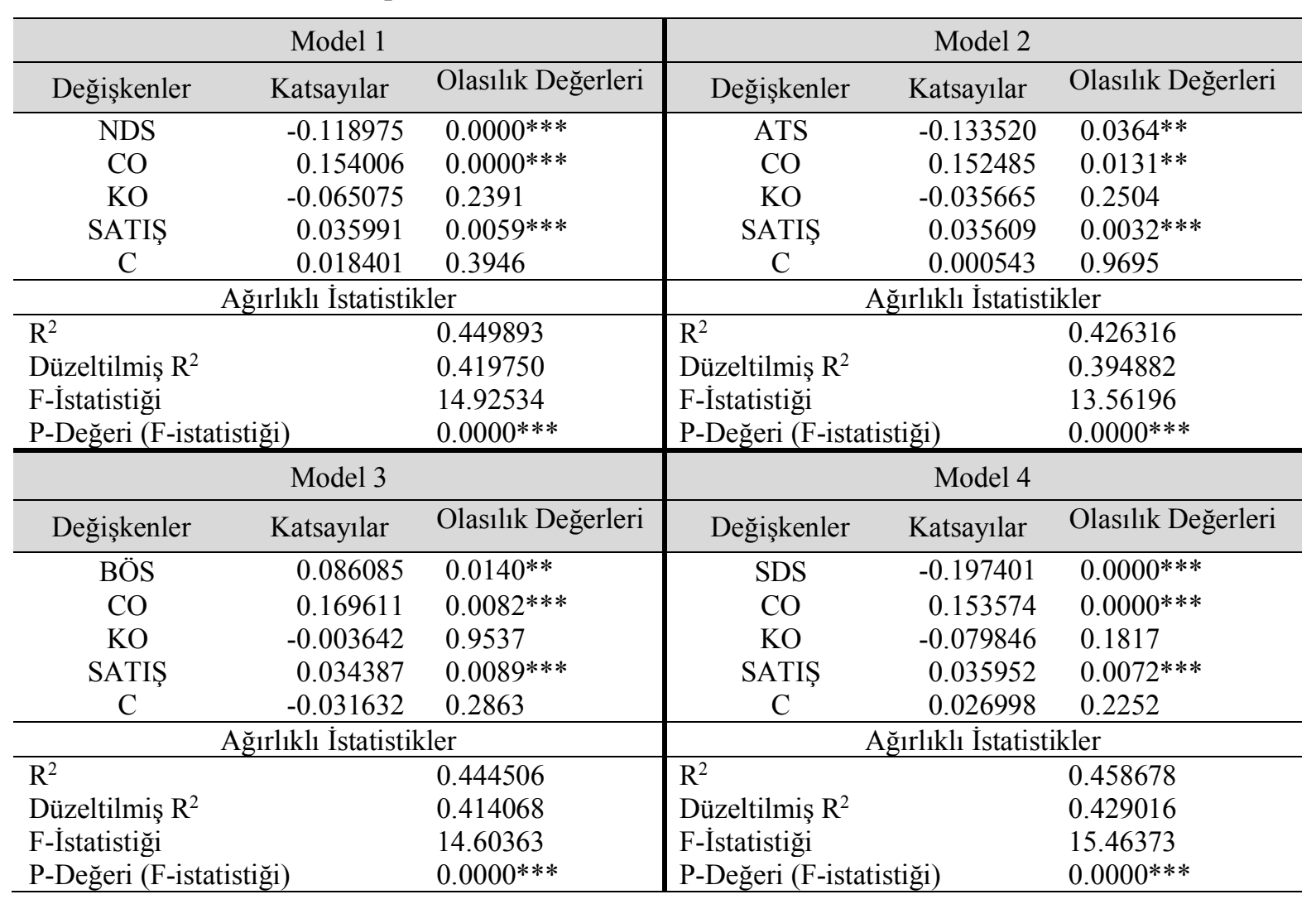


Tablo 8'de yer alan istatistiklere göre, dört modelin de $\% 1$ anlamlılık düzeyinde (P-Değeri $0.000<0.01)$ anlamlı modeller oldukları görülmektedir. Dolayısıyla dört model için de çalışma sermayesi yönetimi ile firma karlılığ 1 arasında istatistiki olarak anlamlı bir ilişkinin varlığını ifade eden H1 hipotezi kabul edilmiştir. Model 1'e ait $\mathrm{R}^{2}$ değeri \%44.98, Model 2'ye ait $\mathrm{R}^{2}$ değeri \%42.63, Model 3'e ait $\mathrm{R}^{2}$ değeri \%44.450 ve Model 4'e ait $\mathrm{R}^{2}$ değeri \%45.86 olarak elde edilmiştir. Dolayısıyla Model 1'e dahil edilen bağımsız değişkenler turizm firmalarının faaliyet karlılıklarındaki değişimleri \%44.98 oranında açıklayabilirken, Model 2'ye dahil edilen bağımsız değişkenlerde bu oran $\% 42.63$, Model 3'e dahil edilen bağımsız değişkenlerde \%44.45 ve Model 4'e dahil edilen bağımsız değişkenlerde ise \%45.86 olarak gerçekleşmiştir. Modellere ilişskin $\mathrm{R}^{2}$ değerleri incelendiğinde, modellerin bağımlı değişken olan faaliyet karlılığındaki değişimleri açıklama güçlerinin birbirine yakın olduğu görülmektedir. Nakit dönüşüm süresi bileşenlerinden olan stok devir süresinin bağımsız değişken olarak yer aldığı Model 4'ün en yüksek $\mathrm{R}^{2}$ değerine sahip olduğu tespit edilmiştir. Buna karşın alacak tahsil süresinin bağımsız değişken olarak yer aldığ1 Model 2'nin en düşük R2 değerine sahip olduğu tespit edilmiştir.

Model 1'e ilişkin panel regresyon sonuçlarına göre, NDS değişkeni ile FKAR değişkeni arasında istatistiksel olarak anlamlı negatif bir ilişki, CO değişkeni ve SATIŞ değişkenleri ile FKAR değişkeni arasında ise istatistiksel olarak anlamlı pozitif bir ilişki bulunmaktadır. KO değișkeni ile FKAR değişkeni arasında ise istatistiksel olarak anlamlı bir ilişki bulunmamaktadır. Sonuçlara göre, nakit dönüşüm süresinde meydana gelecek bir birimlik bir artış turizm firmalarının faaliyet karlılıklarında \%11.89'luk bir azalışa sebep olacaktır. Bunun yanı s1ra, cari oranda meydana gelecek bir birimlik bir artış firmaların faaliyet karlılıklarında \%15.40'l1k bir artışa, satışlardaki büyümede meydana gelecek bir birimlik bir artış ise firmaların faaliyet karlılıklarında \%3.59'luk bir artışa sebep olacaktır.

Model 2'ye ilişkin panel regresyon sonuçlarına göre, ATS değişkeni ile FKAR değişkeni arasında istatistiksel olarak anlamlı negatif bir ilişki, CO değişkeni ve SATIŞ değişkenleri ile FKAR değişkeni arasında ise istatistiksel olarak anlamlı pozitif bir ilişki bulunmaktadır. KO değişkeni ile FKAR değişkeni arasında ise istatistiksel olarak anlamlı bir ilişki bulunma- maktadır. Sonuçlara göre, alacak tahsil süresinde meydana gelecek bir birimlik bir artış turizm firmalarının faaliyet karlılıklarında \%13.35'lik bir azalışa sebep olacaktır. Bunun yanı sıra, cari oranda meydana gelecek bir birimlik bir artış firmaların faaliyet karlılıklarında \%15.24'lük bir artışa, satışlardaki büyümede meydana gelecek bir birimlik bir artış ise firmaların faaliyet karlılıklarında \%3.56'lık bir artışa sebep olacaktır.

Model 3'e ilişkin panel regresyon sonuçlarına göre, BÖS, CO ve SATIŞ değişkeleri ile FKAR değişkeni arasında istatistiksel olarak anlamlı pozitif bir ilişki bulunmaktadır. KO değișkeni ile FKAR değișkeni arasında ise istatistiksel olarak anlamlı bir ilişki bulunmamaktadır. Sonuçlara göre, borçların ödenme süresinde meydana gelecek bir birimlik bir artış turizm firmalarının faaliyet karlılıklarında \%8.60'lık bir artışa sebep olacaktır. Bunun yanı sıra, cari oranda meydana gelecek bir birimlik bir artış firmaların faaliyet karlılıklarında \%16.96'llk bir artışa, satışlardaki büyümede meydana gelecek bir birimlik bir artış ise firmaların faaliyet karlılıklarında \%3.43'lük bir artışa sebep olacaktır.

Model 4'e ilişkin panel regresyon sonuçlarına göre ise, SDS değişkeni ile FKAR değişkeni arasında istatistiksel olarak anlamlı negatif bir ilişki, CO değişkeni ve SATIŞ değişkenleri ile FKAR değişkeni arasında ise istatistiksel olarak anlamlı pozitif bir ilişki bulunmaktadır. KO değişkeni ile FKAR değişkeni arasında ise istatistiksel olarak anlamlı bir ilişki bulunmamaktadır. Sonuçlara göre, stok devir süresinde meydana gelecek bir birimlik bir artış turizm firmalarının faaliyet karlılıklarında \%19.74'lük bir azalışa sebep olacaktır. Bunun yanı sıra, cari oranda meydana gelecek bir birimlik bir artış firmaların faaliyet karlılıklarında \%15.35'lik bir artışa, satışlardaki büyümede meydana gelecek bir birimlik bir artış ise firmaların faaliyet karl11ıklarında \%3.59'luk bir artışa sebep olacaktır.

Panel regresyon modellerinin sonucunda nakit dönüşüm süresi ve bileşenlerine ilişkin olasılık değerleri karşılaştırıldığında NDS ve SDS değişkenlerinin \%1 anlamlılık düzeyinde anlamlı oldukları, ATS ve BÖS değişkenlerinin ise $\% 5$ anlamlılık düzeyinde anlamlı oldukları tespit edilmiştir. Dolayısıyla NDS ve SDS değişkenlerine ilişkin katsayıların ATS ve BÖS değişkenlerine ilişkin katsayılara kıyasla daha anlamlı oldukları söylenebilir. Değişkenlere ilişkin katsayılar in- 
celendiğinde SDS değişkeninin FKAR değişkeni üzerinde en anlamlı ve en yüksek değişime sebep olan değişken olduğu görülmektedir. Bu anlamda SDS değişkenini sırasıyla NDS, BÖS ve ATS değişkenleri takip etmektedir.

\section{Sonuç ve öneriler}

Çalışma sermayesi yönetimi ile firma karlılı̆̆ arasındaki ilişkinin incelendiği bu çalışmada, BİST'de işlem gören 6 turizm firmasinın 2011:12-2017:12 dönemi yarıyıllık verileri kullanılarak firmaların çalışma sermayesi yönetimleri ile faaliyet karlılıkları arasındaki ilişki panel regresyon analizi ile incelenmiştir. Çalışmada turizm firmalarının çalışma sermayesi yönetimi ile karlılıkları arasındaki ilişki dört farklı model üzerinden incelenmiştir. Model 1'de nakit dönüşüm süresi, Modeli 2'de alacak tahsil süresi, Model 3'te borçların ödenme süresi, Model 4'te ise stok devir süresi bağımsız değişken olarak ele alınmıştır. Çalışma sermayesi yönetimi ile ilgili literatürde sıklıkla kullanılan değişkenlerden olan cari oran, finansal kaldıraç oranı ve satışlarda büyüme oranı da modellere bağımsız değişken olarak dahil edilmiştir. Çalışmada analizler makro panel regresyon yaklaşımı kullanılarak gerçekleştirilmiştir.

Yapılan analiz sonucunda, dört modelin olasılık değerleri de 0.05 kritik değerinin altında olduğundan modellerin istatistiki olarak anlamlı olduğu belirlenmiştir. Dolayısıyla dört modelden de çalışma sermayesi ile faaliyet karlılığ 1 arasında istatistiksel olarak anlamlı ilişkilerin varlığına yönelik bulgular elde edilmiştir. Analiz sonucunda nakit dönüşüm süresi, alacak tahsil süresi ve stok devir süresi değişkenleri ile firma karlılı̆g 1 arasında istatistiki olarak negatif anlamlı ilişki, borçların ödenme süresi, cari oran ve satışlarda büyüme değişkenleri ile firma karlılığ rak pozitif anlamlı ilişki tespit edilmiştir. Dolayısıyla çalışmanın sonuçları doğrultusunda, turizm firmalarının karlılıkları üzerine çalışma sermayesi yönetiminin etkileri incelenirken nakit dönüşüm süresi ve bileşenleri özelinde; kısa ve uzun vadeli ticari borçlarını ödeme süresinde artış, stok devir süresi, alacak tahsil süresi ve genel olarak nakit dönüşüm süresinde azalış meydana gelmesi durumunda firma karlılığının artacağı beklentisinden söz etmek mümkündür. Aynı şekilde cari oran ve satışlarda büyümede meydana gelecek artışlarda firma karlılığının artacağına yönelik bek- lentilerden söz edilebilir. Çalışmada, genel olarak finans teorisine uygun ve çalışma sermayesi ile firma karlılığı arasındaki ilişkiyi inceleyen çalışmalara benzer sonuçlar elde edildiği söylenebilir. Elde edilen sonuçların nakit dönüşüm süresi ve bileşenlerinin firma karlılığına etkileri noktasında Wang (2002), Deloof (2003), Lazaridis ve Tryfonidis (2006), Karaduman vd. (2010), Coşkun ve Kök (2011), Dursun ve Ayrıçay (2012), Engvist vd. (2014), Atmaca (2016) ve Keskin ve Gökalp (2016)'in çalışmalarında elde edilen sonuçlarla birbirini doğruladıkları söylenebilir. Çalışma sonuçlarının, pay yatırımcılarına, firma yönetimlerine, araştırmacı ve analistler gibi farklı çevrelerden ilgililere yatırım veya analiz yaparken daha etkili kararlar verme noktasında yardımcı olacağı düşünülmektedir. Çalışmanın sonuçları değerlendirilirken, çalışmanın ele alınan örneklem ve dönem bağlamında kısıtlara tabi olduğu ve çalışmanın dönem itibarıyla bir kriz sonrası dönemi kapsadığı unutulmamalıdır.

\section{Kaynakça}

Açıkgöz, E., Uygurtürk, H., \& Korkmaz, T. (2015). Analysis of factor affecting growth of pension mutual funds in Turkey. International Journal of Economics and Financial, 5(2), 427-433.

Afeef, M. (2011). Analyzing the impact of working capital management on the profitability of SME's in Pakistan. International Journal of Business and Social Science, 2(22), 173-183.

Agha, H. (2014). Impact of working capital management on profitability. Eueopean Scientific Journal, 10(1), 374381.

Akoto, R. K., Awunyo-Vitor, D., \& Angmor, P. L. (2013). Working capital management and profitability: Evidence from Ghanaian listed manufacturing firms. Journal of Economics and International Finance, 5(9), 373-379.

Arshad, Z., \& Gondal, M. Y. (2013). Impact of working capital management on profitability a case of the Pakistan cement industry. Interdiciplinary Journal of Contemporary Research in Business, 5(2), 384-390.

Ata, H. A., \& Buğan, M. F. (2016). İmalat şirketlerinde çalışma sermayesi etkinliğinin firma değerine etkisi nasıldır?. Selçuk Üniversitesi Sosyal Bilimler Enstitüsü Dergisi, 35, 25-33.

Atmaca, M. (2016). Finansal oranlar aracılığıyla çalışma sermayesi bileşenlerinin karlllığa etkisi: Borsa İstanbul'da işlem gören kimya, plastik ve kauçuk şirketlerinde bir araştırma. Yönetim Bilimleri Dergisi, 14(28), 633-649.

Baltagi, B. H. (2014). Econometric analysis of panel data. Fifth Edition. Chichester: Jhon Wiley\&Sons Ltd. 
Baltagi, B. H., \& Li, Q. (1995). Testing AR (1) against MA (1) disturbances in an error component model. Journal of Econometrics, 68(1), 133-151.

Born, B., \& Breitung, J. (2016). Testing for serial correlation in fixed-effects panel data models. Econometric Reviews, 35(7), 1290-1316.

Breusch, T. S., \& Pagan, A. R. (1979). A simple test for heteroscedasticity and random coefficient variation. Econometrica, 47(5), 1287-1294.

Coşkun, E., \& Kök, D. (2011). Çalışma sermayesi politikalarının karlılık üzerine etkisi: Dinamik panel uygulaması. Ege Akademik Bakış, 11, 75-85.

Deloof, M. (2003). Does working capital management affect profitability of Belgian firms?. Journal of Business, Finance and Accounting, 30(3), 573-587.

Dursun, A., \& Ayrıçay, Y. (2012). Çalışma sermayesi-karlılık ilişkisinin İMKB örneğinde 1996-2005dönemi analizi. Atatürk Üniversitesi İkitisadi ve İdari Bilimler Dergisi, 26(3-4), 199-214.

Engvist, J., Graham, M., \& Nikkinen, J. (2014). The impact of working capital management on firm profitability in different business cycles: Evidence from Finland. Research in International Business and Finance, 32, 36-49.

Finnet: www.finnet.com.tr, [Erișim Tarihi: 14.07.2018]

Garcia-Truel, P. J., \& Martinez-Solano, P. (2007). Effects of working capital management on SME profitability. International Journal of Manegerial Finance, 3(2), 164177.

Gilll, A., Biger, N., \& Mathur, N. (2010). The relationship between working capital management and profitability: Evidence from the United States. Business and Economics Journal, 10, 1-9.

Gujarati, D. N. (2004). Basic econometrics. Fourth Edition. New York: The McGraw-Hill Companies.

Güldeci, E. N. (2016). İşletme düzeyinde çalışma sermayesi ve karlılık ilişkisi - Bist'de faaliyet gösteren gübre işletmeleri üzerine bir çalışma. Yaşam Bilimleri Dergisi, 6(2/1), 183-192.

Helhel, Y., \& Karasakal, S. (2017). Konaklama işletmelerinde çalışma sermayesi yönetiminin karlılık performansina etkisi: Borsa İstanbul'da (Bist) bir uygulama. Seyahat ve Otel İşletmeciliği Dergisi, 14(3), 27-39.

Hsiao, C. (2006). Panel data analysis - advantages and challenges. Institute of Economic Policy Research. Univercity of Southern California, Working Paper.

Im, K.K., Pesaran, M.H., \& Shin, Y. (2003). Testing for unit roots in heterogeneous panels. Journal of Econometrics, $115,53-74$.

KAP: www.kap.org.tr, [Erişim Tarihi: 13.07.2018].

Karaduman, H. A., Akbaş, H. E., Ozsozgun, A., \& Durer, S. (2010). Effects of working capital management on profitability: The case for selected companies in the Istanbul
Stock Exchange (2005-2008). International Journal of Economics and Finance Studies, 2(2), 47-54.

Kendirli, S., \& Çankaya, M. (2016). BİST turizm endeksindeki şirketlerde işletme sermayesi yönetiminin karlılık üzerindeki etkisini ölçmeye yönelik bir araştırma. International Review of Economics and Management, 4(2), 46-68.

Keskin, R., \& Gökalp, F. (2016). Çalışma sermaye yönetiminin firma kârlılığı üzerine etkisi: Panel veri analizi. Doğuş Üniversitesi Dergisi, 17(1), 15-25.

Korkmaz, T., Yıldız, B., \& Gökbulut, R.İ. (2010). FVFM'nin İMKB ulusal 100 endeksindeki geçerliliğinin panel veri analizi ile test edilmesi. İstanbul Üniversitesi Işsletme Fakültesi Dergisi, 39(1), 95-105.

Köse İçigen, F., \& Karaş, G. (2017). İşletme sermayesi yönetiminin karlılık üzerine etkisinin araştırılması. Kırklareli Üniversitesi İktisadi ve İdari Bilimler Fakültesi Dergisi, 6(4), 55-60.

Lazaridis, I., \& Tryfonidis, D. (2006). The relationship between working capital management and profitability of listed companies in the Athens Stock Exchange. Journal of Financial Management and Analysis, 19(1), 1-12.

Levin, A.T., Lin, C.F., \& Chu, C.S.J. (2002). Unit root tests in panel data: Asymptotic and finite sample properties. Journal of Econometrics, 108(1), 1-24.

Meder Çakır, H. (2013). Nakit döngüsünün firma karlılığına etkisinin sektörel analizi. Journal of Yaşar University. 30(8). 4948-4965.

Nazir, M. S., \& Afza, T. (2009). Impact of aggressive working capital management policy on firms' profitability. The IUP Journal of Applied Finance, 15(8), 19-30.

O'Brien, R. M. (2007). A calculation regardingrules of thumb for Variance Inflation Factors. Quality and Quantity, 41(5), 673-690.

Pesaran, M. H., \& Yagamata, T. (2008). Testing slope homogeneity in large panels. Journal of Econometrics, $142,50-93$.

Pesaran, M. H., Ullah, A., \& Yagamata, T. (2008). A biasadjusted LM tes of error cross-section indipendence. Econometrics Journal, 11, 151-127.

Singh, j. J., \& Pandey, S. (2008). Impact of working capital management in the profitability on hindalco industries limited. The Icfai University of Financial Economics. 6(4), 62-72.

Tatoğlu, F. Y. (2013). Panel veri ekonometrisi: Stata uygulamall. İstanbul: Beta Basım.

Ün, T. (2015). Stata ile panel veri analizi. S. Güriş (eds.) Stata ile panel veri modelleri. (ss. 39-80). İstanbul: Der Kitabevi.

Wang, Y. J. (2002). Liquidity management, operating performance, and corporate value: Evidence from Japan and Taiwan. Journal of Multinational Financial Management. 12, 159-169. 


\section{Extended abstract in English}

The companies, which have to operate under the conditions of intense competition both in national and international markets, need an effective working capital management on important issues such as sustaining their production continuously, working at full capacity, continuing their activities efficiently and profitably, reducing liquidity risks and increasing their credit worthiness. In the simplest form working capital management represents the value of current assets in a firm. The working capital elements mainly consist of cash and cash equivalents, trade receivables and investments in inventories. Therefore, working capital is related to the necessary funds for a firm to accomplish it daily activities. Short-term liabilities are used in the financing of the working capital which denotes the short-term assets. Commercial debts, especially in the financing of stocks, constitute an important source of finance by spreading the cash outflow over time. The level of harmonization between current assets and short term liabilities is the main objective of working capital management.

The most commonly used criterion for the measurement of working capital management is the Cash Conversion Cycle. Cash Convesion Cycle is calculated by subtracting the Accounts Payables Period from total of the Inventory Turnover Period and the Accounts Receivables Period. Extending the Cash Conversion $\mathrm{Cy}$ cle may increase the profitability due to the increase in sales. In addition, if the cost of investment in working capital is greater than the benefit of the investment in inventories and trade receivables, extending the Cash Conversion Cycle may reduce the profitability.

In this study, it is aimed to examine the relationship between working capital management and firm profitability for the period after the 2008 crisis by using the data of 2011:12-2017:12 period for 6 tourism companies traded in Borsa Istanbul (BIST). When the related literature is examined, it has been seen that the profitability of the firms is generally represented by Operating Profitability Ratio and Return on Assets Ratio, while working capital management is represented by Cash Conversion Cycle and its components. In the studies in the literature, Financial Leverage Ratio, Current Ratio and Growth Rate in Sales are often included in the models as control variables. In this study, as dependent variable; Operating Profitability Ratio is used, and as independent variables; Cash Conversion Cycle and its components, Accounts Payables Period, Inventory Turnover Period and Accounts Receivabes Period, which are considered as the main indicator of working capital management, are used. Cash Conversion Cycle and its components are used as indipendent varables in separate models. In addition, Financial Leverage Ratio, Current Ratio and Growth Rate in Sales are included in each model as control variables. In accordance with the related literature, it was intended to include more selected financial ratios to the models as indipendent variables. However, as the high correlation observed between financial ratios would cause multi-collinearity problems, some financial raitos were excluded from the study.

In this study, the relationship between the profitability of tourism firms and working capital management was investigated by panel data analysis. Multicollinearity, unit root, cross-sectional dependency, autocorrelation and heteroskedasticity were tested as assumptions before panel regression models were estimated. According to the results of the study, Cash Conversion Cycle, Accounts Receivables Period and Inventory Turnover Period have statistically negative significant effects on firm profitability and Accounts Payables Period have statistically positive significant effects on firm profitability. Likewise, Current Ratio and Growth Rate in Sales have statistically positive significant efffects on firm profitability. In the light of the results of the study, it is possible to mention the expectation that profitability of tourism firms will increase in case that Cash Conversion Cycle, Accounts Receviables Period and Inventory Turnover Period decrease, and that Accounts Payables Period, Current Ratio and Growth Rate in Sales increase. According to the results, it can be said that similar results have been obtained in accordance with financial theory in general and the studies examining the relationship between working capital and company profitability 